Article

\title{
Wind Power Deployment: The Role of Public Participation in the Decision-Making Process in Ontario, Canada
}

\author{
Anahita A. Jami ${ }^{1, *}$ and Philip R. Walsh ${ }^{2}$ \\ 1 Yeates School of Graduate Studies, Ryerson University, 350 Victoria Street, Toronto, ON M5B 2K3, Canada \\ 2 Entrepreneurship \& Strategy, Ted Rogers School of Management, Ryerson University, 575 Bay Street, \\ Toronto, ON M5G 2C5, Canada; prwalsh@ryerson.ca \\ * Correspondence: anahita.asadolahniaj@ryerson.ca; Tel.: +1-416-979-5000 (ext. 2553)
}

Academic Editor: Kannan Govindan

Received: 3 May 2016; Accepted: 15 July 2016; Published: 26 July 2016

\begin{abstract}
A wider use of renewable energy is emerging as a viable solution to meet the increasing demand for global energy while contributing to the reduction of greenhouse gas emissions. However, current literature on renewable energy, particularly on wind power, highlights the social barriers and public opposition to renewable energy investment. One solution to overcome the public opposition, which is recommended by scholars, is to deploy a collaborative approach. Relatively little research has specifically focused on the role of effective communication and the use of a knowledge-broker in collaborative decision-making. This study attempts to fill this gap through the proposition of a participatory framework that highlights the role of the knowledge-broker in a wind project decision-making process. In this paper, five illustrative wind projects in Ontario are used to highlight the current situation with public participation and to address how the proposed framework could have improved the process. Based on the recommended collaborative framework, perception must shift from the dominant view of the public as "a risk to be managed" towards "a resource that can be tapped". The developers need to improve sharing what they know and foster co-learning around questions and concerns.
\end{abstract}

Keywords: collaborative approach; knowledge-broker; wind energy; participatory framework

\section{Introduction}

A wider use of renewable energy is seen as one way to meet increasing global energy demand and to fulfill set targets for greenhouse gas reduction [1]. Wind power has been seen as a promising substitute for conventional sources of electricity because of the abundance of wind, the adaptability of wind power to existing land use, its nonpolluting character, and an increasing cost effectiveness [2,3]. However, development of wind power has proven to be an uphill challenge. The industry, especially in Ontario, Canada, has been less than successful in convincing the public of the merits of wind energy. Despite broad support for renewable energy in general and wind energy in particular, there are many cases in Ontario where opponents have stopped wind energy development [4]. What differentiates wind power from other forms of renewable energy such as solar is its visibility in the landscape, which has become one of the main factors in public opposition [3]. The case study results of this research indicate that the visibility issues are related to aesthetics and the fear of plummeting property values. These are perceived values that need consideration and deeper dialogue to be resolved. Furthermore, some members of the community whose land is leased for wind farms earn annual rental income for hosting the wind turbines whereas their neighbors feel that they are inequitably dealt with, having incurred the bother of these adjacent structures without any form of compensation. 
Public objections raise questions regarding the factors that affect community acceptance of wind energy projects, e.g., what can be done to increase the public acceptance? One solution recommended by the literature is to deploy a collaborative approach [5-7]. Based on previous research done by the authors [8], the extant literature extensively supports the notion that the social acceptability of wind projects depends on three factors: public engagement into the decision-making process, addressing the public concerns, and incorporating their suggestions. This concept provides the opportunity to practice participatory decision-making in order to preemptively inform people of the project's development. In this way, they tend to feel less threatened and are able to consider the potential benefits of the project, and be more likely to react positively [8].

While the benefits of public involvement are undeniable, their participation has its own challenges. Wolsink [6] states that communication is the principal problem to be dealt with during the decision-making process on developing wind facilities. Communicators miss their targets when they do not provide meaningful information to the public, do not address the real concerns of people, and do not provide them with timely feedback. Relatively little research has specifically focused on the role of effective communication and the use of a trusted third party in the decision-making process. For the purpose of our research, this third party will be referred to as a knowledge-broker and defined as a skilled third party who attempts to facilitate creative problem solving through communication and analysis, aided by social-scientific knowledge of conflict. This study attempts to fill this gap through the proposition of a participatory framework that highlights the role of the knowledge-broker in a wind project decision-making process. In this paper, five illustrative wind projects in Ontario are used to highlight the current situation of public participation and to address how the proposed knowledge-broker/participatory framework could have improved the process.

\section{Background}

\subsection{Weaknesses of the Current Regulatory Governance}

All renewable energy projects in Ontario are subject to one of the following approval streams: the Environmental Assessment (EA) process or the Renewable Energy Approval (REA) process [9]. We will discuss each of them in further detail.

\subsubsection{Environmental Assessment}

Prior to the introduction of the REA process, wind projects over two megawatts (MW) were required to complete an Environmental Screening Report (ESR) pursuant to the Electricity Projects Regulation (O. Reg. 116/01) [10] associated with the Environmental Assessment Act. After the completion of an ESR, municipal zoning approval was also required. In some cases, the Canadian Environmental Assessment Agency (CEAA) determines whether or not a federal EA (or CEA) on a specific project is required. This determination is based on the potential for environmental effects in areas of federal jurisdiction, i.e., federal lands; effects that cross provincial boundaries; and effects that impact Aboriginal people.

One of the purposes of the EA is to ensure that opportunities are provided for public participation. However, project proponents are mainly responsible for managing public involvement programs, yet they have no clear guidance as to how to manage these programs. Furthermore, there are no criteria or standards available for gauging the adequacy of the public involvement programs [11]. Therefore public engagement in the EA is typically restricted to providing public notification about proposed developments, and the submission of written comments by the respondents. While this may seem a good starting point for public engagement, in practice it is difficult for the public to make substantive comments about complex technical and scientific issues; this becomes more challenging when information on environmental assessment is not available in plain language. Even after submitting their comments-despite all challenges and difficulties-there is no guarantee that feedback will be provided to participants [12]. 
The spectrum of participation ranges from providing information to the public to actual empowerment that places final decision-making in the hands of the public. Figure 1 demonstrates that in Ontario, public participation in wind project development processes generally falls within the "inform" and "consult" areas of the spectrum. The statutory requirements of Ontario's EA legislation [13] have led to initial decisions being made by developers, announced to the public and then defended against public criticism. The role of the public in this "decide-announce-defend" model of decision-making becomes one of providing criticism rather than support.

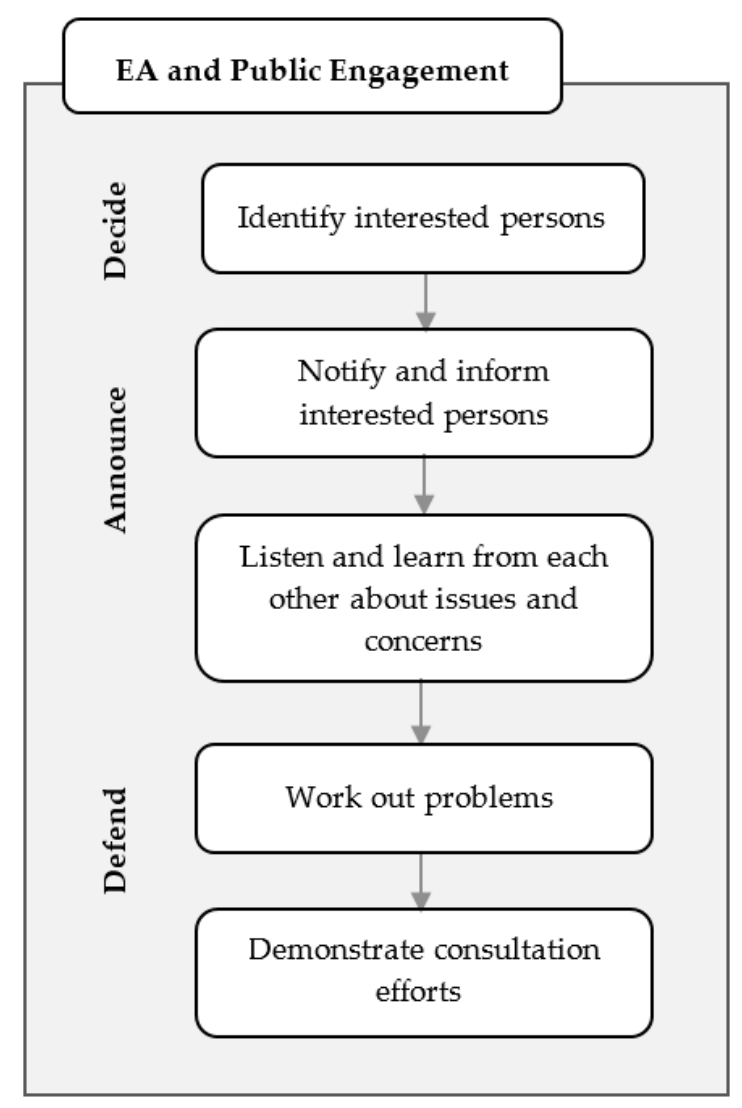

Figure 1. Public participation model arising from Ontario's EA legislation.

Many scholars point out that involvement typically happens in the latter stages of project planning when different potential alternatives are already narrowed down prior to consulting with the public. One of the fundamental challenges of Ontario's EA is to achieve a meaningful public participation leading to sustainable decision-making [14]. Sustainable decision-making generally involves a range of social, environmental, economic, political, and ethical factors which need to be in balance in order to reach a consensus and in turn, a sustainable society [15]. However, since the introduction of the Environmental Assessment Act, the EA has been a source of criticism and disappointment in this regard [14].

\subsubsection{Renewable Energy Approval}

As part of the Green Energy and Green Economy Act, the Ministry of Environment established a new Renewable Energy Approval process. The Renewable Energy Approval Regulation under the Environmental Protection Act (O. Reg. 359/09) [16] came into force on 24 September 2009. Only turbines three kilowatts $(\mathrm{kW})$ or less are exempt from preparing a REA. Any facility over $50 \mathrm{~kW}$ with a sound power rating of 102 decibels $(\mathrm{dB})$ or greater is required to meet an absolute minimum setback 
of $550 \mathrm{~m}$ from the nearest receptor. Furthermore, municipal zoning approval is no longer required leaving municipalities to be included in the general consultation process only.

The REA regulation is not an amendment to the Environmental Assessment Act. It was enacted under the Environmental Protection Act. Therefore, all wind projects are removed from the existing federal-provincial environmental assessment coordination agreement. If a CEA is required, two separate and distinct documents must be submitted. To meet the obligations of the REA regulation regarding public engagement, developers only need to provide notifications and hold two public meetings in each local municipality in which the project is situated (Figure 2). The developers are required to hold one or more public meetings if there is a change to the project. The purpose of these meetings is to provide the general public with information about their project and to gather feedback.

\begin{tabular}{|c|c|c|c|c|c|c|}
\hline $\begin{array}{l}\text { Notice of } \\
\text { project or notice } \\
\text { of first public } \\
\text { meeting } \\
\text { Draft project } \\
\text { description } \\
\text { report made } \\
\text { available } \\
\text { Municipal } \\
\text { Consultation } \\
\text { Form to } \\
\text { Municipality }\end{array}$ & $\begin{array}{c}\text { First } \\
\text { public } \\
\text { meeting }\end{array}$ & $\begin{array}{c}\text { Draft } \\
\text { reports } \\
\text { made } \\
\text { available to } \\
\text { municipality }\end{array}$ & $\begin{array}{l}\text { Notice of final } \\
\text { public } \\
\text { meeting } \\
\text { Draft reports } \\
\text { made } \\
\text { available }\end{array}$ & $\begin{array}{l}\text { Final public } \\
\text { meeting } \\
\text { Developer } \\
\text { revises and } \\
\text { submits REA } \\
\text { application }\end{array}$ & $\begin{array}{c}\text { REA } \\
\text { application } \\
\text { accepted } \\
\text { and posted } \\
\text { on the ERB } \\
\text { for } 30 \text { days }\end{array}$ & $\begin{array}{c}\text { Notice of } \\
\text { application } \\
\text { published } \\
\text { All reports } \\
\text { posted on } \\
\text { developer's } \\
\text { website } \\
\text { REA } \\
\begin{array}{c}\text { Decision } \\
\text { Issued }\end{array}\end{array}$ \\
\hline \multirow[t]{2}{*}{30 Days } & & & 60 Days & & 10 Days & \\
\hline & & \multicolumn{2}{|c|}{90 Days } & & \multicolumn{2}{|c|}{6 Months } \\
\hline Aboriginal Consult & ion (contin & dous from an ear & stages in the proj & & & \\
\hline
\end{tabular}

Figure 2. REA regulation and public participation [9].

Local communities can appeal the REA decisions through the Ontario Environmental Review Tribunal (ERT). ERT is an administrative tribunal established by provincial legislation, which holds hearings and issues decisions, reports, or recommendations based on law, evidence, and the duty to protect the environment [17].

As witnessed in Ontario, a regulatory framework where public participation is limited to a legal obligation to only consult leads to public opposition, a lack of municipal support, subsequent delays, and the risk of cancellation of the wind energy project [18]. With a more collaborative approach, where public participation occurs in the early stages of the project, developers can address the concerns of the network of opponents prior to finding themselves in a project with a tight deadline and limited progress on public consensus. This latter approach is consistent with practices in many European countries, particularly Germany (a leading jurisdiction in the use of wind and solar power in Europe), which has established a stable regulatory framework, based on strong environmental awareness, comprehensive legislation, and political commitments to renewable energy targets [8].

\subsection{Collaborative Decision-Making}

Collaborative planning (CP) or communicative planning is a recent approach to public participation. Collaborative behavior is strongly desirable as a way to manage and resolve conflicts 
and also for the achievement of integrative agreements between stakeholders [19]. Patsy Healey was a pioneer in developing collaborative planning. Healey [20] defined collaborative planning as a collective process for resolving conflicts and advancing shared visions involving a set of diverse stakeholders.

Collaborative planning seeks to involve the key (if not all) stakeholders in the decision-making process to achieve consensual policy outcomes and balanced solutions for the benefit of all. This is achieved through debate under the conditions of effective communication. Collaborative planning is based on an interactive and interpretive process; therefore, interaction, communication, and negotiation among stakeholders are its vital elements [20]. As mentioned earlier, Wolsink [6] also placed emphasis on the importance of communication in the context of wind energy projects. He believes poor communication plays an important role in the failure to develop a wind project; communication misses its targets when it does not address the affected public's concerns.

Since the public is one of the key stakeholders in any large-scale renewable energy project, public participation in a friendly and supportive environment becomes an essential factor in collaborative planning, ensuring full consideration of the public interest. It is important to note that: (1) Stakeholders are those who are affected by the planning or decision-making, where they share risks, costs, and benefits; (2) they have a right to participate; and (3) they can affect the decision-making process both negatively and positively. The other important components of a collaborative planning process are: the integration of different forms of knowledge (e.g., local and expert knowledge); mutual and social learning; criticism with respect; and trust [21]. The latter is vitally important because only stakeholders who trust each other can begin to communicate effectively and work towards collaboration [21]. The starting point is the sharing of meaningful information as well as feedback amongst stakeholders. Trust begins to grow by everyone considering each stakeholder's comments and concerns when choosing alternatives, planning, and making a final decision.

As indicated in Figure 3, a collaborative approach is comprised of three main phases of negotiation in which there are distinct steps [22]. Negotiation is a powerful method for conflict resolution and requires special skills and experience. It is most frequently deployed when important issues must be agreed upon. Negotiation is also necessary when one party requires the other party's agreement in order to achieve a mutually satisfactory resolution. The aim of negotiation is to create shared goals or positions leading in some cases to long-term relationships [19] and can sometimes involve a neutral third party to extract the issues from the manifesting emotions of negotiating parties, thereby keeping the parties focused on the resolution of those issues [23].

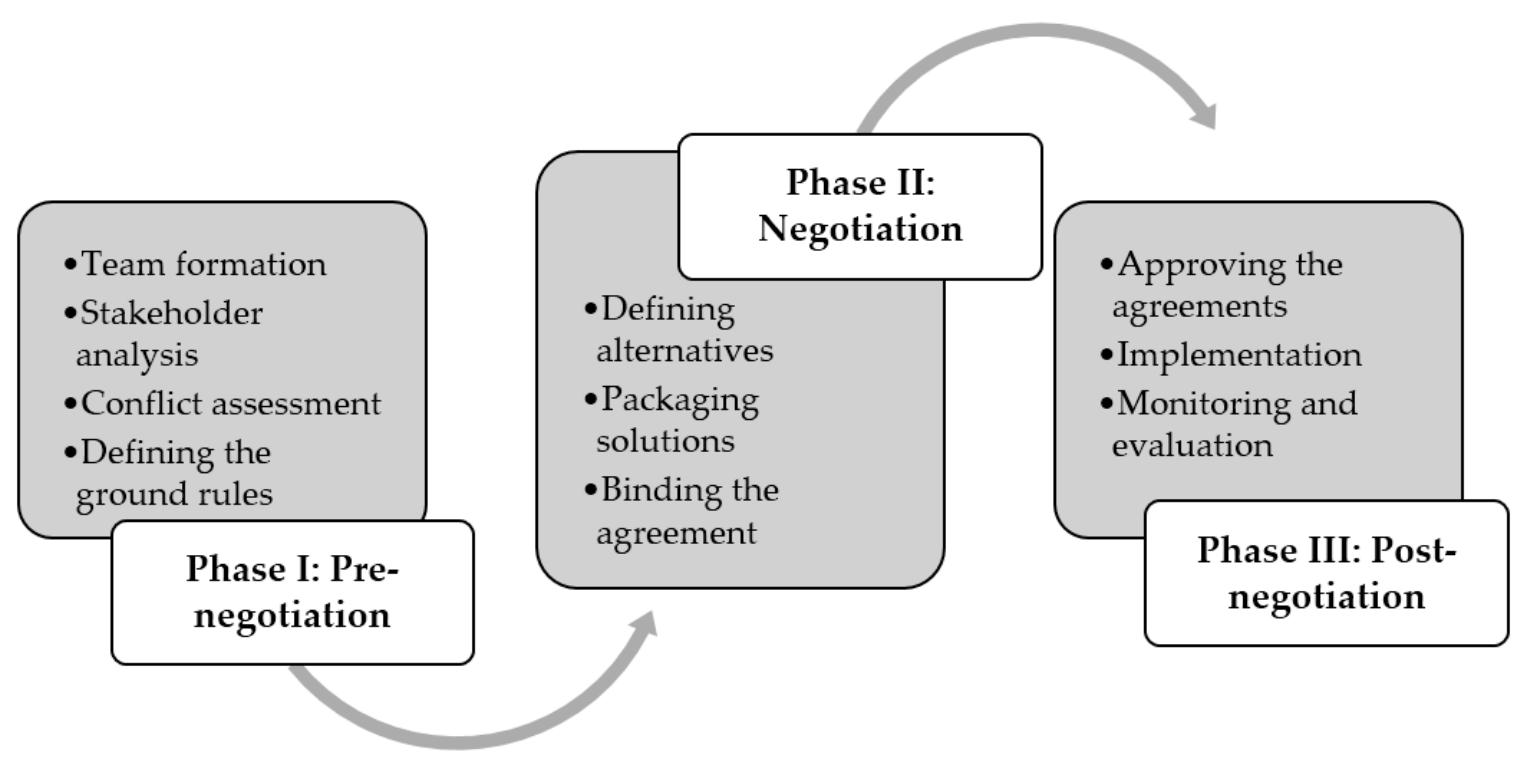

Figure 3. Different phase and steps of collaborative decision-making. 
As Lewicki, et al. [24] explain, third parties usually do not have a strong partisan position on the issues in dispute; therefore, they can attempt to help parties reach a settlement. There are different types of third parties, for instance a mediator, arbitrator, conciliator or consultant [25]. Regardless of their classification, these particular third parties have a common objective: to affect an agreement between the negotiating parties. There are many fragmented studies (largely by discipline) about a third party's role and style that will be discussed later, however there is still no universally accepted definition of a third party who mediates a negotiation.

Many authors have identified the benefits of adopting a collaborative approach to resolve disputes and to reach a consensus. Table 1 indicates some advantages and challenges of the collaborative approach cited in the literature and summarized by Day and Gunton [22] and Finnigan [26].

Table 1. Advantages and challenges of the collaborative approach.

\begin{tabular}{|c|c|}
\hline Advantages & Challenges \\
\hline $\begin{array}{l}\text { Reducing conflicts: Collaborative planning is more } \\
\text { likely to result in a decision because stakeholders are } \\
\text { constructively incorporated into a collaborative } \\
\text { process to reach a consensus, instead of remaining as } \\
\text { critics outside the process. }\end{array}$ & $\begin{array}{l}\text { Motivation and skills: All stakeholders (both } \\
\text { proponents and opponents) should be motivated to } \\
\text { participate. However, the asymmetrical distribution } \\
\text { of negotiating skills and technical knowledge can } \\
\text { result in inequitable outcomes. }\end{array}$ \\
\hline $\begin{array}{l}\text { Creative solutions: Integration of local and expert } \\
\text { knowledge may result in more creative alternatives. }\end{array}$ & $\begin{array}{l}\text { Representativeness: Stakeholder groups willing and } \\
\text { able to participate in collaborative planning may } \\
\text { represent a narrow spectrum of special interests that } \\
\text { exclude broader public interests and can therefore } \\
\text { result in biased decisions. }\end{array}$ \\
\hline
\end{tabular}

Reaching efficient decisions: The broad and diverse group of stakeholders improves the quality of decisions by incorporating interests of all parties in the final plan. Therefore, solutions to problems are better supported for implementation.

Creation of social capital: The development of improved skills, knowledge, and stakeholder relationships that benefit the community in ways beyond preparation of the specific project.

Increased equity, building trust, improving officials' credibility within the community, and improved public understanding of the agency's responsibilities and limitations are among advantages.
Logistical challenges: Organizing a process around a large group of potentially resistant stakeholders requires substantial resources and time.

Compromise: Stakeholders may agree on the second-best solution in order to achieve consensus. In some cases, even important expert knowledge can be underemphasized or overlooked.

A collaborative approach may not be appropriate in many situations that involve fundamental value and belief differences.

The greatest barriers for the public are: time commitments, financial resources required for effective participation, and potential power imbalances. However, a collaborative approach can provide unique opportunities for stakeholders to present ideas within an equitable and respectful environment. Innes and Booher [27] put an emphasis on the importance of information in the decision-making process. They believe the biggest issue in participation is the trustworthiness of information, and who controls it. In collaborative participation, joint fact-finding is conducted in which the parties can question data and present their own. If this dialogue goes well, even when someone does not agree with the final result, they may accept the fairness of the decision if they can see the transparency of the process [27].

\subsection{The Role of a Trusted Third Party in Collaborative Decision-Making}

As referenced earlier, there is growing agreement regarding the advantages afforded to authorities who collaborate from the beginning with the public in the decision-making process. This collaboration can be reached through a trusted third party. His or her role is to be a bridge between the two communities by establishing an effective communication process. Many terms that describe this 
third party are often used interchangeably, such as mediator, knowledge-broker, facilitator, boundary spanner, change agent, collaborative entrepreneur, intermediary, arbitrator, conciliator, and consultant. According to Rogers [28], in the knowledge transfer process the successful diffusion of proper ideas and technologies relies on the existence of change agents (knowledge-brokers) to tackle the conflicts and influence the decision-making processes in a direction deemed desirable by all stakeholders in order to reach consensus. Therefore, they function as linkage agents to move knowledge, skills, or fact-based information from the knowledge producer to the users of that knowledge, and to convey feedback from the users to the knowledge producer. While early studies in this area have focused on mediation, arbitration, and consultation, current studies have utilized a more integrated and knowledge-based approach that moves towards the understanding of the causes, factors, and dynamics of conflict itself as well as the role of the third party to resolve conflict and reach consensus.

Partidario and Sheate [29] (p. 27) define knowledge brokerage as "a mechanism for transferring research evidence into policy and practice, and as a way of breaking down barriers that impede interaction, healthy communication, and collaboration. Through knowledge sharing and exchange, mutual learning processes can be stimulated, increasing the potential to build capacity among stakeholders and improve outcomes". The knowledge brokerage concept was born in the health sector and rapidly expanded to the business world and environmental field where policy problems are increasingly associated with complexity, uncertainty, and public opposition.

Cooper [30] suggests that the exact role and function of the third party are conceptualized differently in various sectors and contexts; however, a key common feature is the facilitation of information exchange among stakeholders. In other words, a knowledge-broker is the catalyst for effective communication by providing meaningful information and nurturing the relationships among stakeholders. Information exchange can occur mutually with specific attention to opportunities that maximize the benefit of all stakeholders, as determined by the expertise of the knowledge-broker [31].

Fullan [32] found that psychologically, people are more likely to exhibit helpful behavior to those similar to themselves. In this way, ideas are more likely to be exchanged and modeled in an easier and effective manner. This depends highly on developing an equal partnership between the knowledge-broker-who has a credible and reliable reputation in the community-and the recipients. However, there is an inherent inequality of this relationship, since the knowledge-broker has an elevated status due to her/his expertise [28]. Bandura [33] frames the importance of the role of a knowledge-broker in the knowledge transfer process by observing that knowledge utilization begins when the knowledge-broker establishes a social relationship with the end-users, and initiates knowledge use within a network of social influences.

Choi, et al. [31] argue that not only the public and policy makers, but also scientists and politicians have different goals, languages, attitudes toward information, and perception of time. Therefore, with the case of wind power development, and specifically with regards to the health and ecological concerns, links between scientists and policy makers appear vital in order to educate people about the health myths related to wind turbines. These linkages may prevent the delay or cancellation of negotiated projects, either of which can impact the economics of a project significantly and discourage investors. The suggested solution by Choi, et al. [31] is to use a trusted and knowledgeable mediator (knowledge-broker) to bridge the gap between policy and academic communities, and to simplify the information for both the public and politicians. Therefore, as depicted in Figure 4, a knowledge-broker acts as an intermediary between three communities: the public, politicians and policy-makers, and scientists, nurturing the relationship amongst them and serving as a catalyst for effective communication. This clearly goes beyond a simple linear model of knowledge transfer into multiple ways of connecting people to share ideas and find solutions [29]. 


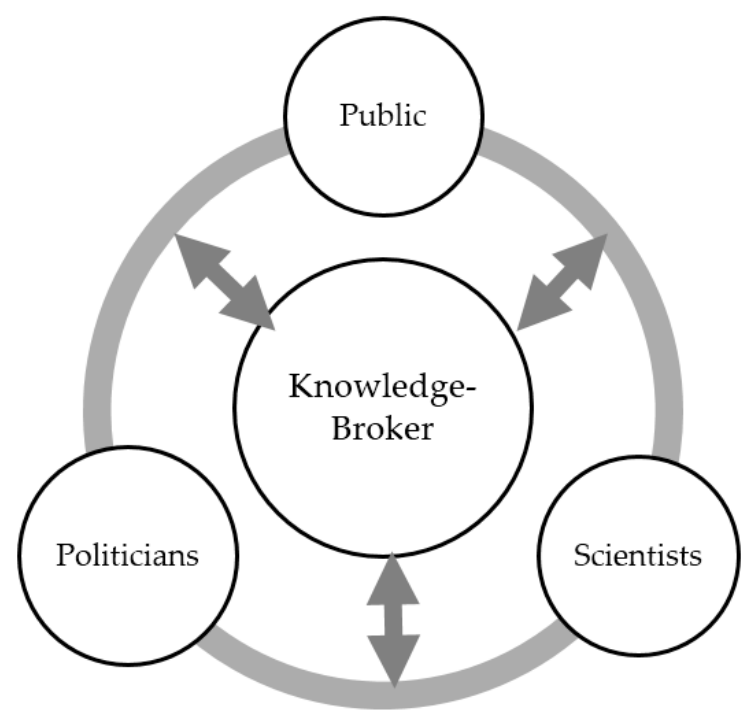

Figure 4. The role of knowledge-broker in connecting different stakeholders.

The factors that could affect the knowledge-broker's success include, but are not limited to, having enough knowledge; understanding local needs; matching local needs with proposed solutions; raising awareness through the introduction of solutions; information sharing and transparency; strength of the interpersonal communication skills; effectiveness of communication skills; and credibility [34].

\section{Recommended Conceptual Framework: Climbing the Ladder of Participation}

As highlighted by the literature, public participation is a continuum or a ladder with each rung representing a more active role for the public in governance decisions. Arnstein's [35] ladder of participation distinguishes between three levels: non-participation, tokenism, and citizen power. Non-participation is a substitute for genuine participation. In other words, the objective of this level is to enable power-holders to educate or cure participant resistance rather than involving them in the planning and decision-making process. Tokenism means providing informing and consultation; this is the opportunity for participants to hear and to be heard, however there is no assurance of feedback and possible changes. Citizen power includes partnership, power delegation and citizen control and at this level citizens can negotiate with power-holders and have the managerial power to make decisions [8].

Arnstein suggests that there is a significant difference between giving people the feeling of involvement and that their claims were considered (while little or nothing changes) and real empowerment. She explains different levels of participation using a typology of eight levels of participation, arranged in a ladder pattern with each rung representing the level of citizens' power in the decision-making processes. The actual level of public involvement is related to how much social power or control they have in the decision-making process. This control or power depends on three factors: bargaining power; financial recourses; and the ability to shape interests in a specific direction (i.e., using media). In order to empower individuals and communities to gain mastery over their affairs, there is a need to increase the community's capacity (e.g., self-esteem, supportive culture, and intellectual resources: knowledge and education) and the capacity of formal institutions (e.g., governmental agencies and corporations) to provide the mechanism for involving the public [36].

Our proposed framework is an effort to encourage the developers to improve the practice of public participation in wind energy projects by deploying a collaborative approach. This may encourage climbing the ladder of participation from simply providing information to entering into a partnership. As demonstrated in Figure 5, the recommended framework is developed based on the three stages of negotiation in collaborative decision-making. In this framework, the initial involvement of interested parties starts with undertaking a stakeholder analysis to identify the main actors in the decision-making 
process, the identification of social networks, and the elicitation of their views with respect to the specific decision to be made. An analysis of stakeholder theory suggests that stakeholders have differing opinions and objectives. Therefore undertaking an analysis to identify what those different interests and goals may be can only assist in finding creative solutions for addressing potential problems [37]. More specifically, stakeholders' preferences are sought to identify decisional criteria to be considered, their relative importance through stakeholder feedback and an investigation of possible solutions. The competent authority in this situation (e.g., a regulator), with the aid of a knowledge-broker would explore the existing conflicts and identify a preliminary list of alternative options. The knowledge-broker becomes a critical catalyst in the formation of collaboration by providing information that is accurate, reliable, and easy to understand.

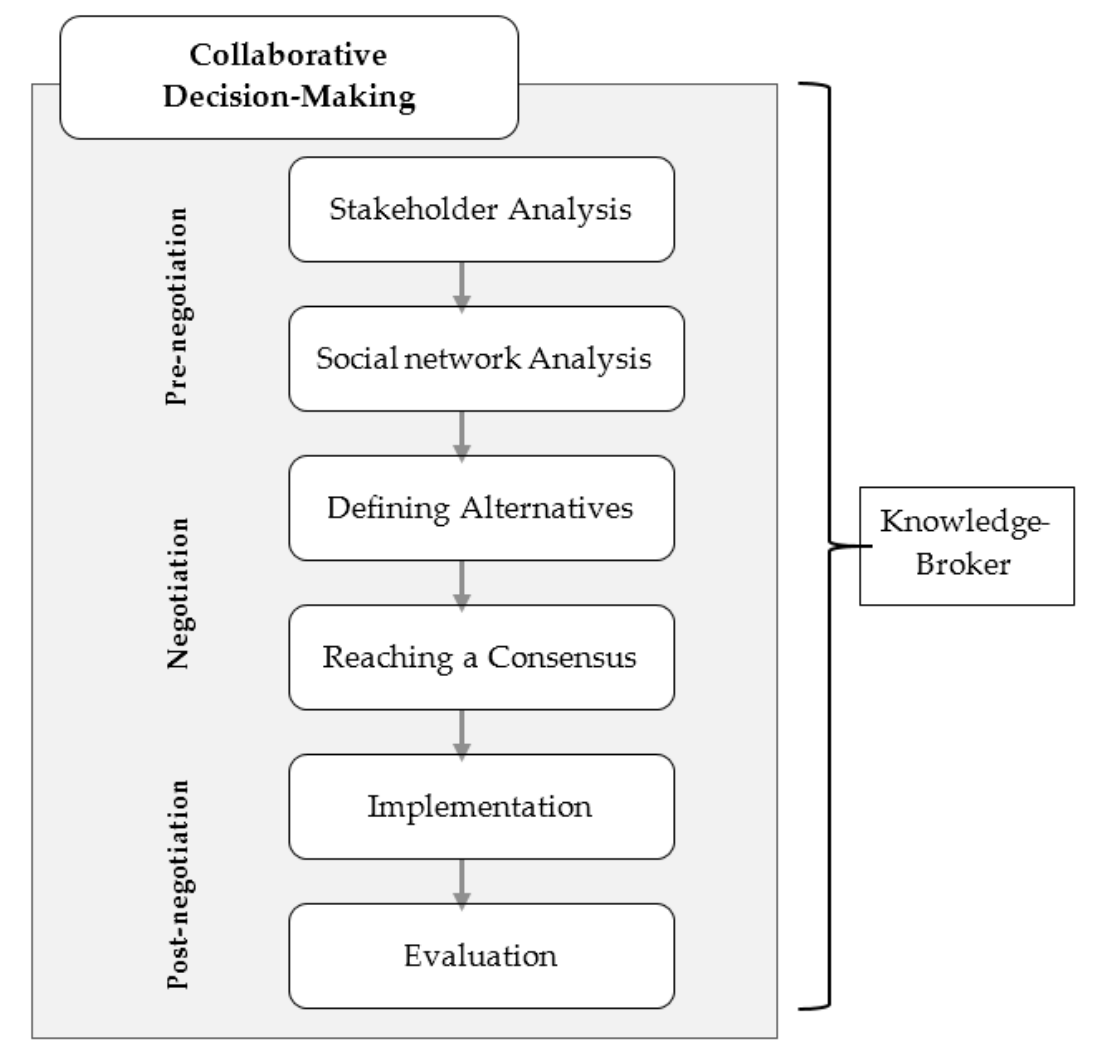

Figure 5. Recommended framework for collaborative decision-making.

A social network analysis is then carried out to explore the relationship among, and between, various actors and the wind energy technology itself. Social network analysis helps with understanding the formation and boundaries of networks, the relationships and interactions between actors within a network and various elements (i.e., social, economic, political, and cultural factors) of a network that create stability. As McLaren Loring [5] describes, the level of network stability is determined by four indicators: a strong relationship among actors within the network; immutable mobiles or the presence of documents within a network which shows the degree of organization; multiplicity or different actors with a range of identities; and critical actors who usually dedicate substantial amounts of time and effort to the process and without whom a network could not form or survive. Critical actors typically bring special skills or knowledge, or a particular conviction, about the project which motivates others. Recent studies suggest that the public's concern regarding the environmental impacts of wind farms can be subjective and that sociological factors, such as a person's knowledge of the technology, exposure to particular media reports, social influences and networks (i.e., the opinion of friends and family living in the local area) are important in determining public perception of wind farms $[7,38]$. 
These two initial steps allow for the creation of a package of assessment data, expert reports, and other research material that would be user-friendly for all stakeholders. This package would clearly articulate the relevance of the opposition network's concerns about the decision-making process and outcomes. As Bijlsma, et al. [39] explain, many social groups feel that the lack of information and opportunities to acquire knowledge are considerable barriers to public participation. Therefore, at this stage, the knowledge-broker can play an important role in tackling this obstacle by familiarizing laypersons with certain information regarding a technical issue and communicating the package in a meaningful way to all stakeholders. Moreover, the knowledge-broker works directly with the public throughout the involvement process to ensure public concerns and aspirations are consistently understood and considered. To establish an information exchange relationship at this stage, the following items should be determined: rules of procedure, roles and responsibilities, timelines, and logistics.

After completing a conflict assessment that evaluates the nature of the conflict and options for resolution, the interests of stakeholders can be identified by the knowledge-broker through brainstorming and idea mapping to define alternatives and encourage principled negotiation. Fisher and Ury [19] defined four elements of principled negotiation: separating the people from the problem; focusing on interests, not positions; inventing options for mutual gain; and insisting on using objective criteria. The next step is to bind the stakeholders to an agreement, followed by implementation, and creating a monitoring process to evaluate implementation. A neutral third party (or knowledge-broker in this context) can help test assumptions and educate where perceptions differ. If emotions run high, a knowledge-broker can encourage involved stakeholders to let off steam and feel heard. Where misunderstanding exists, a knowledge-broker can work to improve communication by conveying fact-based information and feedback between and amongst the stakeholders (developers, local community, experts, municipal and provincial governments). Applying the proposed framework may result in: (1) Flexible decision-making and the enhancement of learning capability; and (2) reaching a wise agreement which, as defined by Fisher and Ury [19], is a durable agreement that meets the legitimate interests of all stakeholders to the extent possible, resolves conflicting interests fairly, and takes community interests into account.

\section{Application of Framework}

\subsection{Methodology}

The Ontario wind energy sector was selected to explore the nature of public participation in wind energy project development due to the presence of active actors and networks of opponents. Moreover, it is in a process of growth in response to government initiatives, i.e., Feed-In-Tariff program. By following the Yin [40] selection criteria, a case study research methodology was chosen for this study mainly because we are exploring the nature of a particular contemporary social phenomenon (public participation) within its real-life context, with boundaries that are not clear between the phenomenon and its context, and where the researchers did not have control over actual behavioral events. The selection of specific cases was guided by the following criteria: the projects were recently finished; there was available information through secondary data (reports and documents); there was a presence of a value/interest conflict; and clear traces of public involvement. To this comparative analysis, the conceptualization of public participation based on collaborative decision-making was applied. This analysis is one component of a larger study on public participation in which we are exploring the role of a knowledge-broker in resolving social conflicts within existing wind energy projects in Ontario. In this paper, we presented the results of our pilot research using mainly secondary data; after choosing case studies, data were collected through project documents, attending public meetings, and conducting pilot interviews. To reveal the common narratives, representatives of key stakeholder groups were interviewed, opponents (local community), proponents (developers), municipalities (planning managers), and involved third parties (consultant and facilitators). 
In order to do the content analysis, make sense of text data, and define the main themes, broad brush coding was utilized to organize the material into topic areas based on the main components of the conceptual framework. The directed content analysis was used for this study because the suggested theoretical framework provided the initial coding scheme.

\subsection{Case Descriptions}

This section provides background information and project overviews regarding selected cases in southern Ontario (Figure 6).

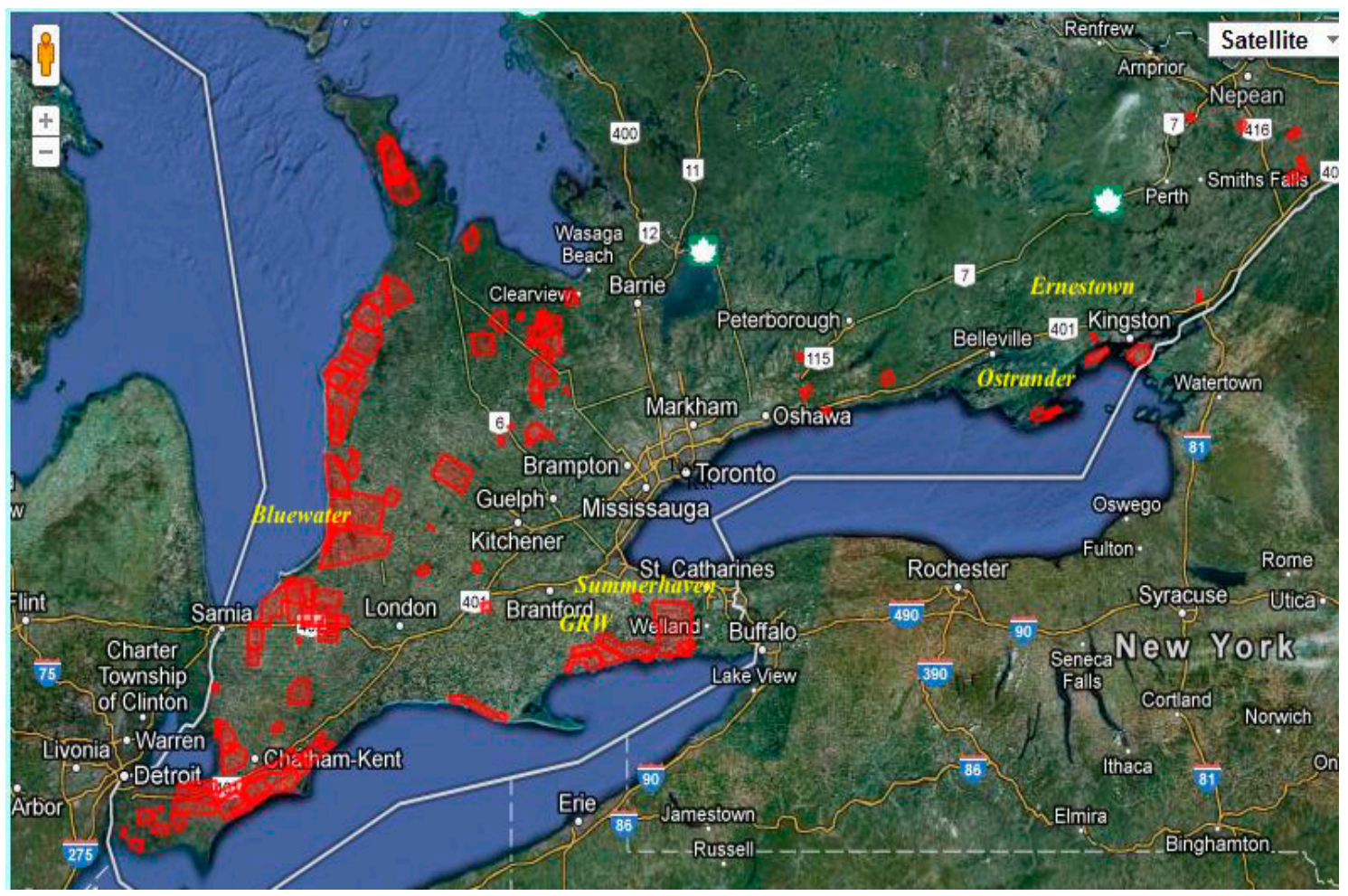

Figure 6. Location of projects (adapted from Ontario Wind Turbines [41]).

4.2.1. Ernestown Wind Park by Horizon Legacy (Project Began in 2010, Intended Start-up in Late 2013, Commercial Operation Began in the Summer of 2014)

The project received a REA in August 2013. This wind energy project has a maximum generating capacity of $10 \mathrm{MW}$ ( 5 turbines). The wind farm is located in Loyalist Township, ON. The first public meeting was held in June 2010 with a subsequent second public meeting. The developer also held six CLC meetings in 2014 (January to September). In 2011 and 2012, they went door to door to meet the neighbors and attended a number of community events in the surrounding communities of Odessa, Amherstview, Bath and Kingston. Ernestown Wind Park is widely known as "the right sized wind park, in the right place". Starting small with a strategic site location which was quite far away from the residential area combined with the presence of a facilitator from the local community who entered the community with credibility, was familiar with the area, and was available to the community, made it easier for the developer to implement the next project in the same area (a solar project).

4.2.2. Summerhaven Project by NextEra Energy (Project Started in 2006, Intended Start-up in 2011, Commercial Operations Began August 2013)

The project received a REA in March 2012. This wind energy project has a maximum generating capacity of 124.4 MW (59 turbines). The wind farm is located in Haldimand County, ON. Three public 
meetings were held in December 2009, December 2010, and January 2011 (additional). There were also four CLC meetings from August 2012 to December 2013. The developer set a teleconference and ran a virtual workshop to answer public questions and concerns. In December 2012, the public advised the developer that a newly-built eagle's nest was in a tree that was scheduled to be removed due to the tree's location immediately adjacent to a proposed wind turbine. After consultation and approval from the Ontario Ministry of Natural Resources, the tree and nest were removed in early January 2013 and a team of experts were employed to install five eagle nesting platforms adjacent to the project along the Lake Erie shoreline in February 2013.

4.2.3. Bluewater Project by NextEra Energy (Project Started in 2006, Intended Start-up in 2013, Commercial Operations Still Pending as at 15 April 2016)

The project received a REA in April 2013. This wind energy project has a maximum generating capacity of $60 \mathrm{MW}$ (37 turbines). The wind farm is located in Bluewater Township, ON. Two public meetings were held in both Bluewater (June 2010 and June 2012) and Huron East (December 2011 and June 2012) municipalities. Four CLC meetings were held between October 2013 and April 2015. Community resistance led to the local municipal council implementing a bylaw that called for a flat fee of $C \$ 14,000$ per turbine for a base permit fee, a $C \$ 220,000$ security charge per turbine for de-commissioning, $C \$ 100,000$ for health, safety and property devaluation, and $C \$ 100,000$ to deal with any future legal fees to the municipality arising from the wind turbines. That brought the total fee to $C \$ 434,000$ for each turbine. In April 2013, the developer launched a legal challenge against the municipality of Bluewater related to their bylaw regarding building permit fees for wind turbines. As of April 2016, the project still awaits commencement of commercial operations.

4.2.4. Ostrander Point Wind Energy Park by Gilead Power (Project Started in 2008, Intended Start-up in 2012, Commencement of Commercial Operations Still Pending as at 15 April 2016)

The project received a REA in December 2012. This wind energy project has a maximum generating capacity of $22.5 \mathrm{MW}$ (9 turbines). The wind farm is located in Prince Edward County, ON. Three public meetings were held (under O. Reg. 116/01 [10] prior to O. Reg. 359/09 [16] enactment) in January 2008, August 2008, and May 2009. In addition, under O. Reg. 359/09, two public meetings were held in November 2010 and April 2011. One CLC meeting was held in June 2013. In July 2013, the ERT revoked Ostrander's REA. The ERT's decision was based on the opinion that the project would cause serious and irreversible harm to the Blanding's turtle, an endangered species, which had been identified in the area. All other grounds of appeal (i.e., impacts to human health, to other animals and plant species) by the Prince Edward County Field Naturalists (PECFN) and the Alliance to Protect Prince Edward County (APPEC) were dismissed by the ERT. The ERT's decision was significant because it was the first appeal in Ontario in which a REA was revoked. The developer took the case to the Divisional Court. In February 2014, The Divisional Court overturned the ERT's decision and reinstated the REA (this was also significant since the Divisional Court generally defers to the ERT as an expert in environmental matters and will not overturn ERT decisions lightly). PECFN appealed the Divisional Court's decision and in April 2015, the Ontario Court of Appeal overturned the Divisional Court's decision and sent the dispute back to the ERT. As a result, although the REA has now gone through three levels of judicial consideration, the status of the REA issued by the MOECC remains unresolved. The developer is currently awaiting a decision from the ERT.

4.2.5. Grand Renewable Wind Project (GRW) by Samsung (with its Local Partner, Pattern Energy) - (Project Started in 2010, Commenced Commercial Operation in 2014)

The project received a REA in June 2012. This wind energy project has a maximum generating capacity of $150 \mathrm{MW}$ (67 turbines). This project is part of what will be the world's largest cluster of wind and solar power. The wind farm is located in Haldimand County, ON. Two public meetings were held in July 2010 and September 2011. There were also four CLC meetings from November 2012 
to November 2014. For the first time in Ontario, the developer has entered into a shared ownership with Six First Nations of the Grand River. Six Nations of the Grand River is comprised of the Mohawk, Seneca, Oneida, Cayuga, Onondaga, and Tuscarora Nations, representing the largest population of all First Nations in Canada. Upon completion, the Six First Nations community owns $10 \%$ of the project. This deal was reached after two years of negotiations between Samsung and the Six Nations. This was a breakthrough due to past incidents with the local indigenous community; for example, a land dispute by Mohawk Six Nations near Caledonia over a housing development that Mohawk Warriors claimed is located on their land led to the occupation of the housing development.

\section{Discussion}

Table 2 summarizes the information of selected projects and primary results of the analysis. From analyzing the publicly available documents and reports, it became clear that there have been only "consultants" and "facilitators" as third parties in the wind decision-making process in Ontario. All five projects had facilitators to run community liaison committees (CLC). They also had consultants (i.e., environmental planners) who helped developers in putting together the renewable energy proposal and preparing related reports (e.g., noise impact assessment report, water assessment report, natural heritage report, archeological report, etc.). However, the role of these third parties was limited and did not go beyond facilitation and consultation. No evidence was found within the cases that a knowledge-broker existed, which was not surprising as there is no such defined role in the decision-making process for wind power development in Ontario.

A closer examination into these projects suggests that most public participation took place after the majority of key construction and operational decisions had been made. As discussed earlier the REA requires two public meetings. The first one is held following the notice of proposal, and the other one following the release of the REA reports. Thirty days prior to the first public meeting, the developers provide a draft of the project description report by posting the drafts on their website, and making paper copies of the drafts available to the public in each local municipality [42]. As shown in Figure 2, the public has 60 days to read, understand and make comments regarding the REA reports. However, in the REA guidelines there are no suggested participatory strategies or clear guidelines that could be adopted by developers to facilitate managing the public participation process. It is each developer's choice as to how to manage the public meetings and prepare reports that contain the main public concerns for the Ministry of Environment and Climate Change (MOECC). The regulations are ambiguous as to whether the developers are obliged to respond directly to the public regarding legitimate concerns pertaining to the proposed wind project.

From the interviews, it is apparent that the developers and the local community had very different views of the proper consultation process. The developers had held a series of public meetings and felt they had made every feasible effort to consult with the fragmented communities. However, the opponents believed large open houses were not an appropriate form of communication. Even though the proponents believed the engagement was project specific, after reviewing consultation reports, attending two public meetings, and analyzing the interviews, it is evident that the developers preferred to choose the public open house format as their main participatory technique. Many respondents (members of local community) had acute feelings of powerlessness with respect to how their concerns or questions influenced the process and the outcome. In all interviews with the opponents, they claimed there was no avenue for public participation. In their opinion, it is merely the ticking of a box for the developers to show that they have conducted public consultation. It was not perceived as sincere and there was no true back and forth communication. 
Table 2. Illustrative projects.

\begin{tabular}{|c|c|c|c|c|c|c|c|c|c|c|c|}
\hline \multirow{2}{*}{ Project } & \multirow{2}{*}{ Duration } & \multirow{2}{*}{$\begin{array}{l}\text { Capacity } \\
\text { (MW) }\end{array}$} & \multirow{2}{*}{ Significant Feature } & \multicolumn{3}{|c|}{ The Presence of a Third Party } & \multicolumn{5}{|c|}{ Participation Level } \\
\hline & & & & Facilitator & Consultant & Knowledge-Broker & Inform & Consult & Involve & Collaboration & Empowerment \\
\hline $\begin{array}{l}\text { Ernestown } \\
\text { Win Park }\end{array}$ & $\begin{array}{l}\text { 2010-2014 (Intended } \\
\text { start-up: 2013) }\end{array}$ & 10 & $\begin{array}{l}\text { Early involvement; } \\
\text { hiring facilitator from } \\
\text { the community }\end{array}$ & $\checkmark$ & $\checkmark$ & - & $\checkmark$ & $\checkmark$ & - & - & - \\
\hline Summerhaven & $\begin{array}{l}\text { 2006-2013 (Intended } \\
\text { start-up: 2011) }\end{array}$ & 124.4 & Eagle nest dispute & $\checkmark$ & $\checkmark$ & - & $\checkmark$ & $\checkmark$ & - & - & - \\
\hline Bluewater & $\begin{array}{l}\text { 2006-Still in } \\
\text { progress (Intended } \\
\text { start-up: 2013) }\end{array}$ & 60 & Municipality bylaws & $\checkmark$ & $\checkmark$ & - & $\checkmark$ & $\checkmark$ & - & - & - \\
\hline $\begin{array}{l}\text { Ostrander } \\
\text { Point Wind } \\
\text { Energy Park }\end{array}$ & $\begin{array}{l}\text { 2008-Still in } \\
\text { progress (Intended } \\
\text { start-up: 2012) }\end{array}$ & 22.5 & Legal actions & $\checkmark$ & $\checkmark$ & - & $\checkmark$ & $\checkmark$ & - & - & - \\
\hline $\begin{array}{l}\text { Grand } \\
\text { Renewable } \\
\text { Wind (GRW) }\end{array}$ & 2010-2014 & 150 & $\begin{array}{l}\text { Financial partnership } \\
\text { with Six First Nations }\end{array}$ & $\checkmark$ & $\checkmark$ & - & $\checkmark$ & $\checkmark$ & $\checkmark$ & - & - \\
\hline
\end{tabular}


The community participants described how the plan for developing a wind facility was usually in place for several years, yet had not been communicated to them until the studies were almost done, the turbine locations had been decided upon, and the developer had gone to the property owners and tried to secure land (typically, before they even spoke to the municipality, let alone the local community). As indicated in the Summerhaven case description, decisions that do not take into account local factors, concerns, and values may raise questions, face public opposition, lead to poorly developed plans that have to be reworked in order to fix flaws, and importantly, fuel distrust. Therefore, these issues can be resolved with collaborative decision-making, which considers knowledge as socially situated rather than merely the domain of the technical or scientific form of knowledge.

Although the public participation process in Ontario wind projects is typically limited to providing notifications, informing and consulting with the public in order to meet the requirements of the REA process, it is fair to recognize that in some cases the developers go beyond the legal requirements and hold more than two public meetings. They also attend a number of community events to share information about the project, keep people informed of their progress, and answer community members' questions about the renewable energy approval process (see the Ernestown Wind Park case description). In one case (the GRW project), the developer entered into a shared ownership arrangement with the First Nation community.

Our observations suggest that both wind energy development and the decision-making process have become emotional issues on the part of the general public. It is important to recognize how scientific studies can be a salient and objective input into the decision-making process. Modern technologies have a high degree of technical complexity and correspondingly have a complex set of potential impacts on human health and the natural environment. Therefore, scientific analysis is required in order to discover which type of impact may be present. As discussed in the Ostrander case description, the scientific studies themselves could become the subject of public controversies and bitter stakeholder conflicts as there are references to other scientific studies which appear to point to different kinds of conclusions and, sometimes, these claims are advanced in the ERT or a courtroom setting. Claims about "phony science", "flawed study designs" and "bias" are repeatedly brought up during the interviews. One strategy to heighten the credibility of scientific assessments (especially where significant perceived risk and benefits are involved) is to communicate the results of such assessments effectively with a collaborative approach. Meanwhile, citizens can be used as local experts and fully engaging them in decision-making can provide developers with a rich and contextualized knowledge of the local area, its people, and the area's political dynamics.

In summary, the current public participation model in Ontario for wind energy projects may be designed to satisfy legal requirements but it is not able to incorporate a broad spectrum of the public interest, nor achieve genuine participation, and does not generally satisfy the members of the public. Practice reveals (as shown in these five illustrative projects) quite a reactive and tardy public consultation performance. The reactive nature of such public participation practices simply increases the problem of participation fatigue, limits the process of learning and reduces power-sharing opportunities [29]. The current regulatory governance process strips Ontario's municipal governments of much of their power to decide whether they want such facilities to be established in their communities. As a result they may show their dissatisfaction by passing a "not a willing host" motion (more than 80 Ontario municipalities have formally declared themselves "not a willing host" to wind power generation projects); and passing bylaws that increases barriers to development (the Bluewater wind project).

Therefore, there is a need for a new way of conceptualizing public participation in the decision-making processes. The proposal put forward in this paper is that participation in approving wind energy projects in Ontario should be collaborative. The adoption of the proposed framework and the presence of a knowledge-broker may help reduce the completion period by providing for a smooth flow of information, effective communication, and decreased public opposition. Early public engagement may lead to better or more competent decisions by the developers through taking 
advantage of local knowledge. It is an opportunity to receive feedback, identify issues, and thereby attempt to address those as best as can be possible.

\section{Conclusions}

Our recommended framework requires all stakeholders to reconsider their current roles in the decision-making process. The public should be encouraged to engage in project planning and monitor the decision-making processes to ensure that their concerns have been addressed. Developers should address public concerns through a collaborative and consensus building process initiated early in their planning process. Federal and provincial governments have to reclaim their role of ongoing leadership and provide better criteria for implementation and evaluation of public participation processes. Finally, the process requires a third party who is not only a mediator but also plays the role of a knowledge-broker to connect with stakeholders, share and exchange knowledge, and work on overcoming barriers. The knowledge-broker can help fulfill the main requirement of collaborative decision-making: effective communication.

Long-term benefits of such a collaborative process go beyond the immediate life of the REA process and specific decision-making case. Knowledge creation and exchange lead to community building and decision-making that reflects the wisdom, experience and voice of local residents. It can eventually enhance trust among stakeholders when they see how their input might be valued instead of being rejected or ignored. This is not possible without acknowledging local knowledge, power sharing, and recognizing other partners in the decision-making process. Inevitably, consensus building or collaborative decision-making takes time, but the involved stakeholders can establish a common understanding on how to find the best possible solution which is less likely to face problems in the implementation phase. Sager and Gastil [43] placed emphasis on the fact that consensus building differs from majority rule decision-making in that everyone involved must agree, sometimes reluctantly, with the final decision. In some cases, these will be difficult decisions which will not make everyone happy, but opposition is nullified because an agreement is reached after all interests are taken into account, all alternatives are discussed, the cost and benefits of the alternatives are analyzed, and the barriers to implementation are evaluated. The implementation may have its own difficulties as unforeseen problems may transpire, but a good collaborative decision-making process builds relationships among stakeholders, allowing the parties to work together to resolve those issues.

This pilot study demonstrated that the outcomes from wind energy decision-making processes remain, to some extent, difficult to predict and understand. This relates not only to renewable energy, but also to facility siting much more broadly (i.e., a landfill or waste management facility). There is insufficient empirical data to suggest what the exact shortcomings of the recommended framework would be. In order to assess the strengths and weaknesses of collaborative processes, and identify best practice guidelines for collaborative planning, comprehensive empirical evaluation of the suggested framework is required. In future projects, emphasis should be placed on how to make the decision-making processes conform more closely to the collaborative approach by involving all key stakeholders, hiring a knowledge-broker, and deploying an interactive and interpretive process to reach shared visions.

\section{Limitations and Future Work}

This research relied on the researchers' interpretations of the current situation of wind project development in Ontario and expectations of future events. This might limit the effectiveness of the recommendations. In future, in-depth, multiple case studies can be conducted to examine the applicability of the conceptual framework in a real-life situation, particularly if knowledge-brokers can be found to be part of the approval process. This would yield important insights as to the usefulness of the knowledge-broker in the decision-making process. 
Author Contributions: As the principle investigator, Anahita Jami designed the research, performed interviews, and analyzed data under Walsh's supervision who provided substantial support and guidance through conducting the research and writing this paper as the co-author.

Conflicts of Interest: The authors declare no conflict of interest.

\section{References}

1. Ariza-Montobbio, P.; Farrell, K.N. Wind farm siting and protected areas in Catalonia: Planning alternatives or reproducing one-dimensional thinking? Sustainability 2012, 4, 3180-3205. [CrossRef]

2. Kaffine, D.T.; McBee, B.J.; Lieskovsky, J. Emissions savings from wind power generation in Texas. Energy J. 2013, 34, 155-175. [CrossRef]

3. Pasqualetti, M.J.; Gipe, P.; Righte, R.W. Wind Power in View: Energy LANDSCAPEs in a Crowded World; Academic Press: San Diego, CA, USA, 2002; pp. 3-30.

4. Wright, Z. A voice for the community: Public participation in wind energy development. Dalhous. J. Interdiscip. Manag. 2012, 8, 1-17. [CrossRef]

5. McLaren Loring, J. Wind energy planning in England, Wales and Denmark: Factors influencing project success. Energy Policy 2007, 35, 2648-2660. [CrossRef]

6. Wolsink, M. Wind power implementation: The nature of public attitudes: Equity and fairness instead of backyard motives. Renew. Sustain. Energy Rev. 2007, 11, 1188-1207. [CrossRef]

7. Eltham, D.; Harrison, G.; Allen, S. Change in public attitudes towards a Cornish wind farm: Implications for planning. Energy Policy 2008, 36, 23-33. [CrossRef]

8. Jami, A.; Walsh, P. The role of public participation in identifying stakeholder synergies in wind power project development: The case study of Ontario, Canada. Renew. Energy J. 2014, 68, 194-202. [CrossRef]

9. Renewable Energy Facilitation Office. Renewable Energy Development: A Guide for Municipalities. Available online: http://www.energy.gov.on.ca/en/renewable-energy-development-in-ontario-a-guidefor-municipalities/ (accessed on 20 August 2014).

10. Government of Ontario. O. Reg. 116/01: Electricity Projects. Available online: https://www.ontario.ca/ laws/regulation/010116 (accessed on 15 August 2014).

11. Sinclair, A.J.; Diduck, A.P. Public involvement in EA in Canada: A transformative learning perspective. Environ. Impact Assess. Rev. 2001, 21, 113-136. [CrossRef]

12. Gibson, H.; Hunsberger, C.A.; Wismer, S. Citizen involvement in sustainability centred environmental assessment follow-up. Environ. Impact Assess. 2005, 25, 609-627.

13. Government of Ontario. Consultation in Ontario's Environmental Assessment Process: Code of Practice. Available online: https:/ / www.ontario.ca/environment-and-energy/consultation-ontarios-environmentalassessment-process (accessed on 15 August 2014).

14. Doelle, M.; Sinclair, A.J. Time for a new approach to public participation in EA: Promoting cooperation and consensus for sustainability. Environ. Impact Assess. Rev. 2006, 26, 185-205. [CrossRef]

15. Hersh, M.A. Sustainable decision-making: The role of decision support systems. IEEE Trans. Syst. Man Cybern. Part. C Appl. Rev. 1999, 29, 395-408. [CrossRef]

16. Government of Ontario. Renewable Energy Approvals under Part V.0.1 of the Act. Available online: https://www.ontario.ca/laws/regulation/090359 (accessed on 15 August 2014).

17. Environmental Review Tribunal. Environmental and Land Tribunal Ontario. Available online: http://elto. gov.on.ca/ (accessed on 20 July 2015).

18. Holburn, G.; Lui, K.; Morand, C. Policy risk and private investment in Ontario's wind power sector. Can. Public Policy 2010, 36, 465-486.

19. Fisher, R.; Ury, W.; Patton, B. Getting to Yes: Negotiating Agreement without Giving in, 3rd ed.; Penguin Books: New York, NY, USA, 2011; pp. 3-41.

20. Healey, P. Collaborative planning in a stakeholder society. Town Plan. Rev. 1998, 69, 1-21. [CrossRef]

21. Kumar, A.; Paddison, R. Trust and collaborative planning theory: The case of the Scottish planning system. Int. Plan. Stud. 2000, 5, 205-223. [CrossRef]

22. Day, J.C.; Gunton, T.I. The theory and practice of collaborative planning in resource and environmental management. Environments 2003, 31, 5-19.

23. Zartman, I.W. Negotiations theory and reality. J. Int. Aff. 1975, 29, 69-77. 
24. Lewicki, R.J.; Weiss, S.E.; Lewin, D. Models of conflict, negotiation and third party intervention: A review and synthesis. J. Organ. Behav. 1992, 13, 209-252. [CrossRef]

25. Wall, J.A.; Blum, M.W. Negotiations. J. Manag. 1991, 17, 273-303. [CrossRef]

26. Finnigan, D.S. An Evaluation of Civil Society Participation in Collaborative Land Use Planning in British Columbia. Master's Thesis, Simon Fraser University, Vancuuver, BC, Canada, 2003.

27. Innes, J.E.; Booher, D.E. Reframing public participation: Strategies for the 21st centry. Plan. Theory Pract. 2004, 5, 419-436. [CrossRef]

28. Rogers, E.M. Diffusion of Innovations, 4th ed.; the Free Press: New York, NY, USA, 1995; pp. 335-369.

29. Partidario, M.R.; Sheate, W.R. Knowledge brokerage-Potential for increased capacities and shared power in impact assessment. Environ. Impact Assess. Rev. 2013, 39, 26-36. [CrossRef]

30. Cooper, A. Knowledge-Brokers-A Promising Knowledge Mobilization Strategy to Increase Research Use and Its Impact in Education; Ontario Institute for Studies in Education: Toronto, ON, Canada, 2010.

31. Choi, B.C.K.; Pang, T.; Lin, V.; Puska, P.; Sherman, G.; Goddard, M.; Ackland, M.J.; Sainsbury, P.; Stachenko, S.; Morrison, H.; et al. Can scientists and policy makers work together? J. Epidemiol. Community Health 2005, 5, 632-637. [CrossRef] [PubMed]

32. Fullan, M.G. Change Forces: The Sequel; Falmer Press: London, UK, 1999; pp. 2-3.

33. Bandura, A. Social Foundations of Thought and Action: A Social Cognitive Theory; Prentice Hall: Englewood Cliffs, NJ, USA, 1986; pp. 142-181.

34. Nishimura, K. Grassroots action for renewable energy: How did Ontario succeed in the implementation of a feed-in tariff system? Energy Sustain. Soc. 2011, 2, 1-11. [CrossRef]

35. Arnstein, S. A ladder of citizen participation. J. Am. Inst. Plan. 1969, 35, 216-224. [CrossRef]

36. De Schutter, J.; Riemer, M. Participatory decision-making models in the context of environmental justice: Are they working? In Proceedings of the 2009 Amsterdam Conference on the Human Dimensions of Global Environmental Change, Amsterdam, The Netherlands, 2-4 December 2009.

37. Matos, S.; Silvestre, B.S. Managing stakeholder relations when developing sustainable business models: The case of the Brazilian energy sector. J. Clean. Prod. 2013, 45, 61-73. [CrossRef]

38. Devine-Wright, P. Beyond NIMBYism: Towards an integrated framework for understanding public perceptions of wind energy. Wind Energy 2005, 8, 125-139. [CrossRef]

39. Bijlsma, J.; Eijndhoven, J.V.; Turkenburg, W. Experiences with public participation in decision-making concerning energy policy in the Netherlands. Bull. Sci. Technol. Soc. 1988, 8, 397-404. [CrossRef]

40. Yin, R. Case Study Research: Design and Methods, 4th ed.; Sage Publications: Los Angeles, CA, USA, 2009; pp. 1-18.

41. Ontario Wind Turbines. Project Area. Available online: http://ontario-wind-turbines.org/owt-maps-c18. html (accessed on 15 August 2015).

42. Government of Ontario. Renewable Energy Approval. Available online: https://www.ontario.ca/page/ renewable-energy-approvals (accessed on 15 August 2014).

43. Sager, K.L.; Gastil, J. The origins and consequences of consensus decision-making: A test of the social consensus model. South. Commun. J. 2006, 71, 1-24. [CrossRef]

(C) 2016 by the authors; licensee MDPI, Basel, Switzerland. This article is an open access article distributed under the terms and conditions of the Creative Commons Attribution (CC-BY) license (http://creativecommons.org/licenses/by/4.0/). 